\title{
Epigenetic Mechanisms of Inflammasome Regulation
}

\author{
Giulia Poli ${ }^{1, *}$, Consuelo Fabi ${ }^{2}$, Marina Maria Bellet ${ }^{1}$, Claudio Costantini ${ }^{1}$ (D), \\ Luisa Nunziangeli ${ }^{3}$, Luigina Romani ${ }^{1}$ and Stefano Brancorsini ${ }^{1}$ \\ 1 Department of Experimental Medicine, University of Perugia, 06132 Perugia, Italy; \\ marinamaria.bellet@unipg.it (M.M.B.); costacla76@gmail.com (C.C.); luigina.romani@unipg.it (L.R.); \\ stefano.brancorsini@unipg.it (S.B.) \\ 2 Department of Surgical and Biomedical Sciences, Urology and Andrology Clinic, University of Perugia, \\ 05100 Terni, Italy; consuelofabi93@gmail.com \\ 3 Polo d'Innovazione di Genomica, Genetica e Biologia, 05100 Terni, Italy; luisa.nunziangeli@gmail.com \\ * Correspondence: poligiulia.mail@gmail.com; Tel.: +39-0744-202-820
}

Received: 1 July 2020; Accepted: 8 August 2020; Published: 11 August 2020

\begin{abstract}
The innate immune system represents the host's first-line defense against pathogens, dead cells or environmental factors. One of the most important inflammatory pathways is represented by the activation of the NOD-like receptor (NLR) protein family. Some NLRs induce the assembly of large caspase-1-activating complexes called inflammasomes. Different types of inflammasomes have been identified that can respond to distinct bacterial, viral or fungal infections; sterile cell damage or other stressors, such as metabolic imbalances. Epigenetic regulation has been recently suggested to provide a complementary mechanism to control inflammasome activity. This regulation can be exerted through at least three main mechanisms, including CpG DNA methylation, histones post-translational modifications and noncoding RNA expression. The repression or promotion of expression of different inflammasomes (NLRP1, NLRP2, NLRP3, NLRP4, NLRP6, NLRP7, NLRP12 and AIM2) through epigenetic mechanisms determines the development of pathologies with variable severity. For example, our team recently explored the role of microRNAs (miRNAs) targeting and modulating the components of the inflammasome as potential biomarkers in bladder cancer and during therapy. This suggests that the epigenetic control of inflammasome-related genes could represent a potential target for further investigations of molecular mechanisms regulating inflammatory pathways.
\end{abstract}

Keywords: inflammasome; microRNA; epigenetic modifications

\section{Introduction}

Inflammasomes are cytoplasmic multiprotein complexes sensing microbial pathogens or detecting sterile danger and mediating the activation of proinflammatory cytokines in the context of the innate immune response [1]. It is acknowledged that the basal levels of the inflammasome components are low to prevent inappropriate activation and that two distinct steps are required for the assembly and function of the inflammasome: a first priming step upregulates the levels of inflammasome components, and a second activation step ignites the oligomerization of inflammasome complex [2]. Among the transcriptional and post-transcriptional mechanisms that control the levels of inflammasome components in basal and activating conditions [3,4], accumulating evidence indicates that epigenetic events may actually play a critical role, the failure of which results in the development of pathological conditions, characterized by either hyper- or hypoactivation of the inflammasome. In this review, starting from the definition of the most important epigenetic modifications and their significance, we summarize evidence suggesting their critical role in the regulation of inflammasome activity and inflammasome-related diseases. 


\section{Epigenetic Modifications}

The regulation of biological processes can be achieved through genetic and epigenetic mechanisms. Epigenetic regulation is traditionally defined as a mechanism generating "potentially heritable changes in gene expression not involving changes in DNA sequence". These changes can be exerted through at least three main mechanisms, including CpG DNA methylation, histones post-translational modifications (PTMs) and noncoding RNA expression [5]. All of these events contribute together to the significant variations in cellular functions within a single organism.

The first mechanism, DNA methylation, occurs upon the addition of a methyl group at the fifth position of the pyrimidine ring of the cytosine residues at the level of $\mathrm{CpG}$ dinucleotides and functionally results in transcriptional repression [6]. DNA methylation has been firmly established as a crucial epigenetic mechanism involved in a number of key processes, including development, aging and carcinogenesis.

Histones represent the proteins around which DNA is wrapped to form the nucleosomes, basic units of the chromatin, and are substrates for a wide range of PTMs occurring at multiple amino acid residues within their N-terminal tails, including phosphorylation, acetylation, methylation, sumoylation, ubiquitylation, ADP-ribosylation, biotinylation and the recently identified serotonylation [7]. Therefore, a large variety of chromatin remodeling enzymes interact with chromatin and are implicated in adding, reading or removing PTMs, collectively influencing the chromatin structure and defining the accessibility of the chromatin to transcriptional expression, thus generating the high level of plasticity of chromatin remodeling [8]. Therefore, alteration in the activity of these enzymes can often result in pathologic conditions [9].

Noncoding RNAs are untranslated transcripts that have important regulatory roles in cellular biology. They can be classified in short, mid and long based on their length [10]. Among noncoding RNAs, microRNAs and long noncoding RNAs (lncRNAs) are the most extensively studied in several pathologies. LncRNAs regulate gene expression by interacting with DNA, messenger RNAs (mRNAs) and proteins, while miRNAs mediate the post-transcriptional repression or mRNA degradation according to epigenetic mechanisms [11,12]. miRNAs belong to short noncoding RNAs with 22-25 nucleotides in length, and their activity is performed with peculiar complementarity miRNA-mRNAs [12].

\section{Inflammasomes and Inflammasome-Associated Diseases}

The scientific evidence of "inflammasome" existence dates back to 2002, when a caspase-activating complex composed of the NLR (nucleotide-binding oligomerization domain, Nod-like receptor) protein, the adaptor ASC (apoptosis-associated speck-like protein containing a CARD) and pro-caspase-1 was identified [13]. Several types of inflammasomes have been identified that can respond to distinct bacterial, viral or fungal infections, cell damage and other stressors, such as metabolic imbalances. Inflammasomes are composed of a sensor, such as pyrin domain containing related protein family (NLRP), absent in melanoma (AIM) 2, CARD domain containing (NLRC) 4, the adaptor ASC and caspase-1. While NLRP1, NLRP3, NLRP6, NLRP7, NLRP12 and AIM 2 depend critically on ASC for the engagement of caspase-1, the inflammasome sensor NLRC4 can directly interact with caspase-1. The regulated activation of inflammasomes after microbial infection or injury is critical for the maintenance of tissue homeostasis, and deregulated inflammasome activity has emerged as a major contributor to the pathogenesis of prevalent diseases, including inflammatory bowel disease, coronary heart disease, autoimmune diseases, neurodegenerative diseases and cancer [14]. Together with Toll-like receptors (TLRs) [15], NLRs belong to the innate immune pattern recognition receptors (PRRs), which are responsible for the recognition of pathogens or tissue injuries through pathogen-associated molecular patterns (PAMPs) and danger-associated molecular patterns (DAMPs), respectively [16]. The culminant event is the production of active caspase- 1 able to process prointerleukin-1 $\beta$ (IL-1 $\beta$ ) into the mature protein IL-1 $\beta$. Progressively, inflammasomes have attracted scientific interest, and nowadays, they are considered crucial mediators of inflammation. 
Currently, NLRPs, AIM2, IFI (interferon- $\gamma$ inducible factor) 16 and RIG-I inflammasomes have been characterized [17]. The NLRP3 inflammasome is the most studied one. Its role has been characterized first in a subset of rare autoinflammatory conditions [18] and, subsequently, in inflammatory [19-23] and metabolic diseases [24]. In contrast, the mechanism of action of other inflammasomes such as NLRP7 [25] and IFI16 [26], have been more recently described. In particular, NLRP7 has been shown to assemble an ASC and caspase-1-containing high molecular weight inflammasome complex in response to bacterial lipopeptides, with a molecular mechanism involving ATP binding and direct ATPase activity [25]. Instead, IFI16 [26] and AIM2 [27] are involved in inducing a caspase-1-activating inflammasome formation by recognizing viral DNA in the nucleus or cytosol, respectively. A recent study identified a mechanism by which AIM2 inflammasome activity is negatively regulated by TRIM11 (tripartite motif 11), determining its degradation via selective autophagy upon viral infection [28]. Recently, novel significantly divergent functions for NLRPs have been identified, in addition to their already well-established proinflammatory functions. This is especially true for NLRP12 and NLRP4. NLRP12 was first described 10 years ago, when a seminal study demonstrated its role as a negative regulator of the nuclear factor kappa-light-chain-enhancer of activated B cells (NF-KB) signaling pathway [29]. NLRP12 plays a crucial role in both the hematopoietic and nonhematopoietic compartment for controlling overt inflammation, colitis and colitis-associated tumorigenesis. The absence of NLRP12 in mice resulted in a severe uncontrolled inflammation that rendered NLRP12-deficient mice highly susceptible to experimental colitis and inflammation-induced tumorigenesis [29]. NLRP4 (a member of the NLR family of the cytosolic receptor strongly expressed in several tissues [30]) has recently been reported as a negative regulator of autophagy and type I IFN signaling, resulting from the interaction of its NACHT domain with Beclin1 and TANK-binding kinase 1 (TBK1), respectively [31]. Furthermore, NLRP4 was identified as an inhibitor of tumor necrosis factor (TNF)- $\alpha$ - and IL-1 $\beta$-mediated NF- $\mathrm{KB}$ activation, which is achieved through an interaction with IKK $\alpha$. The pyrin domain (PYD) of NLRP4 is necessary for this inhibitory effect on NF- $\mathrm{KB}$, underscoring its importance as a critical regulator of inflammatory signaling pathways [32]. Moreover, recent literature frames NLRP4 as an important key mediator during the immune response to viral infections [33].

During the last decades, there has been an explosion in the research field of inflammasomes; the majority of research articles were aimed at the characterization of inflammasomes in noncancerous diseases, ranging from autoimmune diseases, such as arthritis [34-36] and lupus [37,38], to neurodegenerative [39,40], renal [41-43] and vascular diseases [44,45]. The main efforts at dissecting inflammasome mechanisms of action came from studies using murine or cell models of fungal [46-50], bacterial [51-56], viral [57-61] and prion infections [62]. On the one hand, by using animal and cell models, the function of each unit of the inflammasome apparatus can be assessed manipulating its expression. On the other hand, genetic studies uncovering mutations or genetic variants in inflammasome components, conferring the susceptibility for diseases such as diabetes and systemic inflammation [63], provided the complementary side of this intrinsically complex picture. A recent review highlighted the importance of inflammasome-related genes in several major human diseases, by molecular and genetic networks, based on genome-wide association studies [64]. Increasingly available large Omics and clinical data, in tandem with system biology approaches, have offered the opportunity to study more comprehensive and dynamic molecular inflammation networks, showing a double-sword role of inflammasomes. A recent study identified 12 expression profiling datasets derived from nine different tissues isolated from 11 rodent inflammatory disease models related to common chronic diseases. The overlapping of inflammasomes with the innate immunity genes generated a list of six common complex diseases, including obesity, type II diabetes, coronary heart disease, late-onset Alzheimer's disease, Parkinson's disease and sporadic cancer [65]. The crucial crosslink between inflammasomes and immune-related diseases is the activation of IL-1 $\beta$; immune stromal and tumor cells can produce IL- $1 \beta$, which also stimulates the expression of cyclooxygenase (COX)-2, IL-6 and chemokine C-C motif ligand (CCL) [66]. 
Although the importance of IL- $1 \beta$ in cancer is without doubt, the list of its cellular targets is still partially defined. T lymphocytes and myeloid cells are established downstream targets of IL-1 $\beta$; in myeloid cells, IL-1 $\beta$ activates the NF-KB pathway through binding to its receptor, IL-1RI [67]. The ability of IL-1 $\beta$ in inducing angiogenic pathways, which trigger tumor progression, has been widely reported [68], although the mechanisms through which this event occurs have not been completely defined. Due to the relative novelty of this topic, scientific reports dissecting the role of inflammasomes in carcinogenesis are still a minority, compared to infectious and autoimmune diseases. In fact, a plethora of scientific works have been aimed at the characterization of inflammasomes in melanoma [69], leukemia [70] colon [71,72], oral [73] and colitis-associated [74] cancers. Products of inflammasome activation (IL-1 $\beta$ and IL-18) behave as protumorigenic factors in gastrointestinal cancers, while the protective role of NLRP6 against tumor development has been clarified [75], whereas, for NLRC4, contrasting findings were reported [76,77]. A constitutive activation of the NLRP3 inflammasome in late-stage human melanoma cells with the autonomous secretion of active IL-1 $\beta$ has been demonstrated [78]. Knockout mice for IL-1 $\beta$ have reduced the angiogenesis and growth of melanoma tumors [79]. The treatment of metastatic human and mouse melanoma cell lines with the anti-inflammatory phytochemical thymoquinone was shown to hamper the metastasis process by inhibition of the NLRP3 inflammasome [80]. Nonetheless, in hepatocellular carcinoma, the loss in expression of the NLRP3 inflammasome components, both mRNA and protein, was demonstrated and correlated with cancer progression [81].

\section{Epigenetic Regulation of the Inflammasome}

A role for dysfunctional epigenetic mechanisms has been investigated in autoinflammatory diseases, pathological conditions characterized by recurrent episodes of systemic inflammation without infection and autoimmunity [82]. Several genes have now been associated with monogenic autoinflammatory syndromes [83]. For instance, Cryopyrin-associated periodic syndromes (CAPS) are caused by gain-of-function mutations in the NLRP3 gene that result in the constitutive activation of the NLRP3 inflammasome and the release of IL-1 $\beta$, in turn responsible for the symptomatology of the disease [84]. It is clear, however, that the clinical manifestations of autoinflammatory syndromes are variable, and environmental and genetic factors, including epigenetic dysregulation, may contribute to the disease presentation and outcome $[85,86]$. Prompted by the observation that inflammasome-related genes were demethylated during macrophage differentiation and monocyte activation, Vento-Tormo and co-authors analyzed a cohort of patients with CAPS for eventual epigenetic dysregulation [87]. While unstimulated monocytes had similar levels of DNA demethylation in patients and healthy controls, the IL-1 $\beta$ stimulation resulted in a higher demethylation of inflammasome-related genes such as IL1B, IL1RN, NLRC5 and PYCARD in CAPS patients [87]. Of note, the lower methylation levels were observed only in CAPS patients who did not receive the anti-IL-1 treatment, suggesting that IL-1 drives the different methylation patterns [87]. In agreement with these findings, monocytes from patients with chronic nonbacterial osteomyelitis/chronic recurrent multifocal osteomyelitis, an autoinflammatory bone disorder, had reduced methylation levels in the NLRP3 and PYCARD genes compared to healthy controls [88]. Therefore, dysregulated epigenetic mechanisms may contribute to the clinical manifestations of autoinflammatory syndromes by upregulating the expression of inflammasome components. However, this is not a general mechanism, as the same study of Vento-Tormo and co-authors could not identify differences in the methylation patterns between patients with familial Mediterranean fever (FMF), an autoinflammatory disease caused by mutations in the gene $M E F V$ encoding for the pyrin protein, and healthy controls [87]. The low number of patients may have hindered the detection of a statistically significant difference. Alternatively, since lipopolysaccharide (LPS)-stimulated monocytes from FMF patients secrete higher amounts of IL-1 $\beta$ compared to healthy controls in a NLRP3-dependent manner [89], other mechanisms may play a major role in the dysregulation of inflammasome activity. 
The epigenetic regulation of the inflammasome has also been investigated in infectious diseases. For instance, the challenge of TPH-1 with Mycobacterium tuberculosis resulted in the demethylation of the NLRP3 promoter, suggesting that epigenetic mechanisms may contribute to the activation of the inflammasome during infection [90]. In other cases, however, the pathogen co-opts endogenous mechanisms of the epigenetic regulation to downmodulate the inflammasome activation and promote pathogen colonization, as recently demonstrated for Leishmania amazonensis [91]. Indeed, the parasite was able to remodel the chromatin by reducing the H3K9/K14 acetylation and H3K4 trimethylation, resulting in the inhibition of the NF-KB pathway and prevention of NLRP3 activation [91]. Therefore, epigenetic regulation represents a double-edged sword in infectious diseases; on the one hand, it allows inflammasome priming and the activation for a proper response to infections, but, on the other hand, it can be exploited by pathogens to protect them selves from the immune response.

The epigenetic regulation of the inflammasome may also be co-opted in tumors. Indeed, the adaptor protein ASC, also known as target of methylation-induced silencing-1 (TMS1), is a sensitive target of DNA methylation in different tumors, and its demethylation sensitizes cancer cells to apoptosis [92]. In addition, the downregulation of ASC prevents inflammasome assembly and activation [92]. However, while the function of ASC as a tumor-suppressor protein in different types of cancers is acknowledged, the role of inflammasomes is disputed, and pro- and antitumoral effects have been described [93,94]. Therefore, the specific context of each tumor should be carefully evaluated to decide whether ASC de-repression and inflammasome activation would represent a beneficial strategy [95]. The epigenetic dysregulation of the inflammasomes has also been associated with the effects of chemotherapic drugs. For instance, bortezomib, a proteasome inhibitor, promoted histone $\mathrm{H} 3$ and $\mathrm{H} 4$ acetylation on the NLRP3 promoter via STAT3, resulting in the upregulation of NLRP3 expression in dorsal root ganglion, a potential mechanism for bortezomib-induced painful neuropathy [96]. On the contrary, low doses of epirubicin, an anthracycline drug, displayed anti-inflammatory properties by downregulating the NLRP3 inflammasome, and this was associated with a reduction of histone 3 lysine 9 acetylation [97].

Other pathologies have been linked to the dysregulation of epigenetic mechanisms in the control of inflammasome expression. For instance, in the peripheral blood of juvenile spondylarthritis patients, a higher methylation of the NLRP3 gene promoter was observed, in-line with a decreased expression of the protein in these patients, and a vicious cycle of microbiota dysbiosis and reduced NLRP3 inflammasome has been hypothesized to take place in the disease [98]. Conversely, an increased histone acetylation at the NLRP3 promoter and NF-kB activation contributes to the activation of the NLRP3 inflammasome in vascular smooth muscle cells and consequent phenotypic changes and proliferation in hypertension [99]. Moreover, treatments with histone deacetylase (HDAC) 3 inhibitors have been shown to alleviate the inflammatory response and protect against ischemic brain damage by downregulating the AIM2 inflammasome [100]. Similarly, the pharmacological inhibition of the histone demethylase Jumonji domain-containing 3 (Jmjd3) has been associated with reduced inflammation by limiting NLRP3 activation in a murine model of DSS-induced colitis [101].

All in all, the available evidence supports the notion that DNA methylation and histone modifications play a critical role in the regulation of the expression of the inflammasome components, and dysregulation may increase the susceptibility to pathological conditions. It comes that the pharmacological targeting of epigenetic mechanisms might represent a valuable strategy to restore the homeostatic regulation of the inflammasome and balance between the need for inflammasome function in response to environmental cues and the prevention of tissue damage by unrestrained activation.

\section{Role of Noncoding RNA in the Regulation of Inflammasome}

Recent studies demonstrated the post-transcriptional regulation of inflammasomes exerted by miRNA. They can repress or increase inflammasome gene expressions by binding to their mRNA target. In the literature, different miRNAs are known to regulate different inflammasomes. NLRP3 represents the most-studied inflammasome, and some validated miRNAs that exert a post-transcriptional regulation on this are well known. Table 1 shows inflammasome-validated miRNAs. 
Table 1. List of miRNAs known to target inflammasome genes and associated diseases. NLR, NOD-like receptor.

\begin{tabular}{cccc}
\hline miRNA & Target Gene & Disease & References \\
\hline miR-223 & NLRP3 & Inflammatory bowel diseases & {$[102]$} \\
& & Acute lung injury/acute respiratory distress syndrome & {$[103]$} \\
miR-133a & HLRP3 & Inflammatory diseases & {$[104]$} \\
miR-22 & NLRP3 & Gastric cancer & {$[105]$} \\
miR-30e & NLRP3 & Parkinson's disease & {$[106]$} \\
miR-7 & NLRP3 & Parkinson's disease & {$[107]$} \\
miR-199a-3p & NLRP1 & Acute Lung Injury & {$[108]$} \\
miR-146a-5p & NLRP3 & Autoimmune diseases, Multiple sclerosis & {$[109]$} \\
miR-20b-5p & NLRP3 & Multiple sclerosis & {$[110]$} \\
miR-495-3p & NLRP3 & Cardiac injury & {$[4]$} \\
miR-330-3p & NLRP3 & Renal inflammatory disease & {$[111]$} \\
mir-17-5p & NLRP3 & Obesity disease & {$[112]$} \\
mir-141-3p & NLRP3; NLRP4 & Bladder cancer & {$[113]$} \\
miR-372 & NLRP12 & Ulcerative Colitis & {$[114]$} \\
miR-143 & AIM2 & Inflammatory diseases & {$[115]$} \\
miR-18b & NLRP7 & Breast cancer & {$[116]$} \\
\end{tabular}

In 2012, Bauernfeind et al. identified miR-233-3p as the first human miRNA that directly regulates NLRP3. MiR-223 is highly expressed in the myeloid cell lineage, especially neutrophils, and is absent in B cells and T cells, contrary to NLRP3, which results are down-expressed [118]. Moreover, the miR 223-3p decreases and the NLRP3 increases in monocyte differentiation, suggesting that this small noncoding RNA exerts a possible role during this differentiation phase [102]. NLRP3 presents a conserved binding site for miR 223-3p in its $3^{\prime}$ UTR region. The binding between this conserved region and miR 223-3p causes a reduction of NLRP3 activity. Studies in vitro revealed that the NLRP3 target region is conserved among mammals; a mutation in this region causes a complete loss of the miR-223-mediated regulation of the NLRP3 3' UTR [118]. Bandyopadhyay et al. investigated the involvement of miR-133a-1 in inflammasome activation (NLRP3) and IL-1 $\beta$ production [105]. In this work, they overexpressed and suppressed miR-133a-1 in differentiated THP1 cells expressing NLRP3. The overexpression of miR-133a-1 increased caspase- 1 and IL-1 $\beta$ levels in response to inflammasome stimuli. The results demonstrated that miR-133a- 1 does not alter the basal expression of individual components of the NLRP3 complex; however, it regulates IL-1 $\beta$ processing and expression levels of its effector protein caspase-1 [105]. The role of NLRP3 activity was also analyzed in gastric cancer. NLRP3 is markedly upregulated in gastric cancer, which promotes NLRP3 inflammasome activation and IL-1 $\beta$ secretion in macrophages [106]. Li et al. identified miR-22 as constitutively expressed in gastric mucosa, where it directly targets NLRP3 at the transcript level [119]. This binding attenuates NLRP3 oncogenic effects in vitro and in vivo. Moreover, NLRP3 inflammasome can be activated by Helicobacter pylori (H. pylori) infection resulting in IL-1 $\beta$ secretion [119]. The H. pylori infection markedly suppresses miR-22 expression, an event that prevents miR-22 from suppressing NLRP3 expression, attenuating NLRP3-driven cell proliferation and preventing gastric cancer carcinogenesis $[106,120]$.

Other miRNAs can influence the NLRP3 inflammasome, such as miR-21, which is expressed aberrantly and plays a role in LPS-induced septic shock [121]. A recent study investigated the role of this miRNA and demonstrated that miR-21 deficiency inhibited NLRP3, ASC and caspase-1 expressions. They found that knockout mice for miR-21 presented inhibited caspase- 1 activation and IL-1 $\beta$ secretion [122]. Other studies elucidated the role of miR30e in inflammation. This miRNA is a key inflammation-mediated molecule that could be a potential target for NLRP3 [107]. Li et al. found that NLRP3 shows conserved miR-30e binding sites in its $3^{\prime} \mathrm{UTR}$, suggesting a link between miR-30e and NLRP3 inflammasome-mediated neuroinflammation in the pathogenesis of Parkinson's disease (PD). There is evidence that miR-30e improves neuronal damage via negatively regulating 
NLRP3 expression and inhibiting NLRP3 inflammasome activation in induced PD mice models. The post-transcriptional regulation of NLRP3 mRNA and protein expression is negatively regulated by miR30e [107], confirming its critical role in PD pathogenesis [123]. Junn et al. provided a direct link between miR-7 and NLRP3 inflammasome-mediated neuroinflammation in PD pathogenesis. Specifically, it has been known that miR-7 directly regulates $\alpha$-Syn expression in dopaminergic neurons via post-transcriptional regulation and is associated with the pathophysiology of PD [123]. Inflammasomes containing NLRP3 are highly expressed in microglia, and they are essential to the process of neuroinflammation [124]. Activated microglia produce a large number of inflammatory cytokines, contributing to dopaminergic neuronal degeneration [108]. NLRP1 inflammasome, the first inflammasome to be discovered and characterized [17], exhibits post-transcriptional regulation exerted by miRNA. Recent studies demonstrated that NLRP1 is regulated by miR-199a-3p and is significantly downregulated in acute lung injury (ALI) tissues [109]. A microarray analysis revealed the presence of miR-199a-3p in three of the 24 lung tissues collected from donor patients who died with ALI. Moreover, miR-199a-3p downregulation eliminates the inhibition of NLRP1, causing the activation of NLRP1 and pro-IL-1 $\beta$ and pro-IL-18 cleavage mediated by caspase- 1 . Consequently, high levels of IL-1 $\beta$ and IL-18 are produced, further exacerbating the inflammatory response and causing the recurrence of the disease [109]. Recently, an epigenetic role of miRNAs targeting other inflammasome genes has been demonstrated. A recent study identified a conserved binding site for miR-372 in the 3'UTR of NLRP12 and demonstrated that miR-372 is particularly present in the blood and colonic mucosa of ulcerative colitis patients compared with healthy controls. Here, the overexpression of miR-372 significantly decreased the protein expression level of NLRP12, thus inducing excessive inflammatory cytokine production and disease progression [115]. In 2013, Momeni and colleagues demonstrated that the miR-143 transfection in Jurkat cell lines determined the increased level of AIM2 transcript suggesting a possible role of miR-143 in the targeting of AIM2 [116]. Recently, a potential regulatory role of miR-18b on NLRP7 has been shown. In particular, miR-18b was shown to bind a $3^{\prime}$-UTR specific binding site in the NLRP7 gene in a breast cancer cell line, where miR-18b was found upregulated. A miR-18b down-expression in these cells induced an upregulation of NLRP7 that promoted cell migration and metastasis [117].

Finally, it is worth mentioning that our group has recently explored the role of miRNAs targeting and modulating inflammasome components as potential biomarkers in bladder cancer. Our studies demonstrated the variable expression of different NLRP genes, including NLRP3, NLRP4, NLRP9 and NAIP, and of miRNAs targeting these NLRs (miR-146a-5p, miR-106a-5p, miR-17-5p, miR-223-3p, miR-141-3p, miR-19a-3p, miR-145-5p and miR-185-5p) in the urine sediments of patients harboring bladder cancer compared to the control healthy subjects. Specific correlations with the tumor stage, risk of recurrence and response to intravesical Bacillus Calmette-Guérin instillation were identified, thus suggesting that the assessment of the expression level of inflammasome-related genes and their regulatory miRNA could represent a potential reliable noninvasive tool for diagnosis in patients with bladder cancer, as well as predictive markers of the responses to therapy $[114,125,126]$.

\section{Conclusions}

Inflammasomes are important regulators of inflammation. A dysregulation of their expression can cause the onset of different pathologies. Recent studies have identified the role played by epigenetic mechanisms in the modulation of inflammasomes expression. DNA methylation, histone modifications and miRNA inhibitory activity, key players of epigenetic regulation, can act by modulating the expression of inflammasome components. The dysregulation of these mechanisms may increase the susceptibility to pathological conditions (Figure 1), suggesting a potential role of epigenetic factors as pharmacological targets to restore the homeostatic regulation of the inflammasome. 


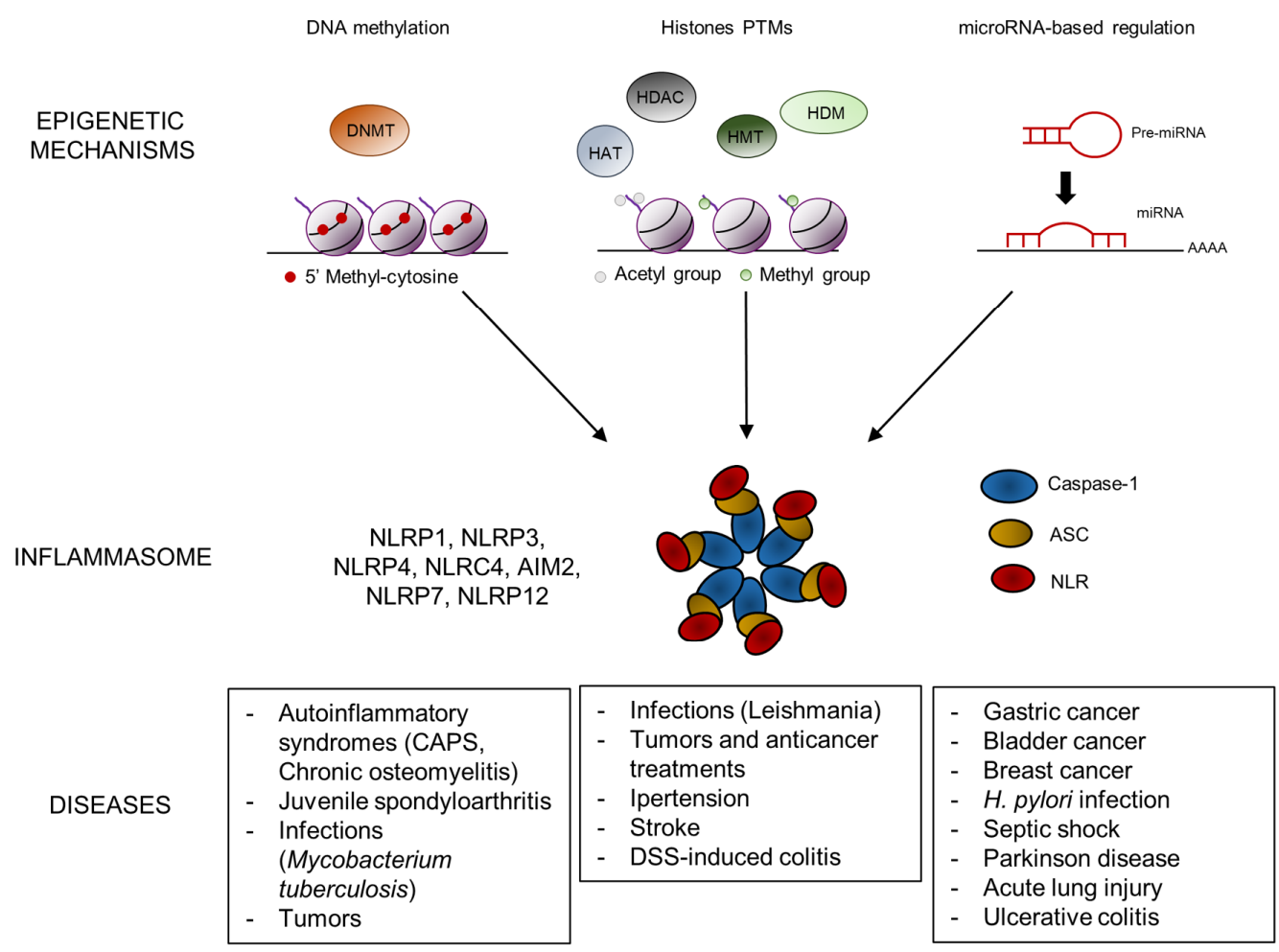

Figure 1. Schematic representation of the main epigenetic mechanisms involved in inflammasome activation. DNA methylation, histones post-translational modifications (PTMs) and microRNA-based regulation exert epigenetic control on the level of inflammasome activity, whose dysregulation may result in the development of inflammasome-related diseases. DNMT, DNA methyltransferases; HAT, histone deacetylases; HDAC, histone deacetylases; HMT, histone methyltransferases; HDM, histone demethylases; ASC, apoptosis-associated speck-like protein containing a CARD; NLR, NOD-like receptor and CAPS, cryopyrin-associated periodic syndromes; DSS, dextran sulfate sodium.

Finally, epigenetic modifications could have valuable importance as pathological predictive biomarkers in biological fluids, as well as in tissues, and the interpretation of epigenetic unbalance could be decisive for the diagnosis of diseases in clinical activity. Although successfully identified in basic research, the knowledge of epigenetic mechanisms is still rarely applied in clinical uses. In the future, clinical studies confirming the pivotal role of epigenetic modulators in diseases such as cancer or neurodegeneration will demonstrate their importance in diagnosis and treatment.

Author Contributions: All authors were involved in conceptualizing the manuscript. All authors have read and agreed to the published version of the manuscript.

Funding: This research received no external funding.

Acknowledgments: This work was supported by Fondazione Cassa di Risparmio Terni e Narni.

Conflicts of Interest: The authors declare no conflicts of interest.

\section{Abbreviations}

AIM

ALI

ASC

CAPS

CCL

COX

DAMPs

FMF
Absent in melanoma 2

Acute lung injury

Apoptosis-associated speck-like protein containing a CARD

Cryopyrin-associated periodic syndromes

Chemokine $\mathrm{C}-\mathrm{C}$ motif ligand

Cyclooxygenase

Danger associated molecular patterns

Familial Mediterranean fever 


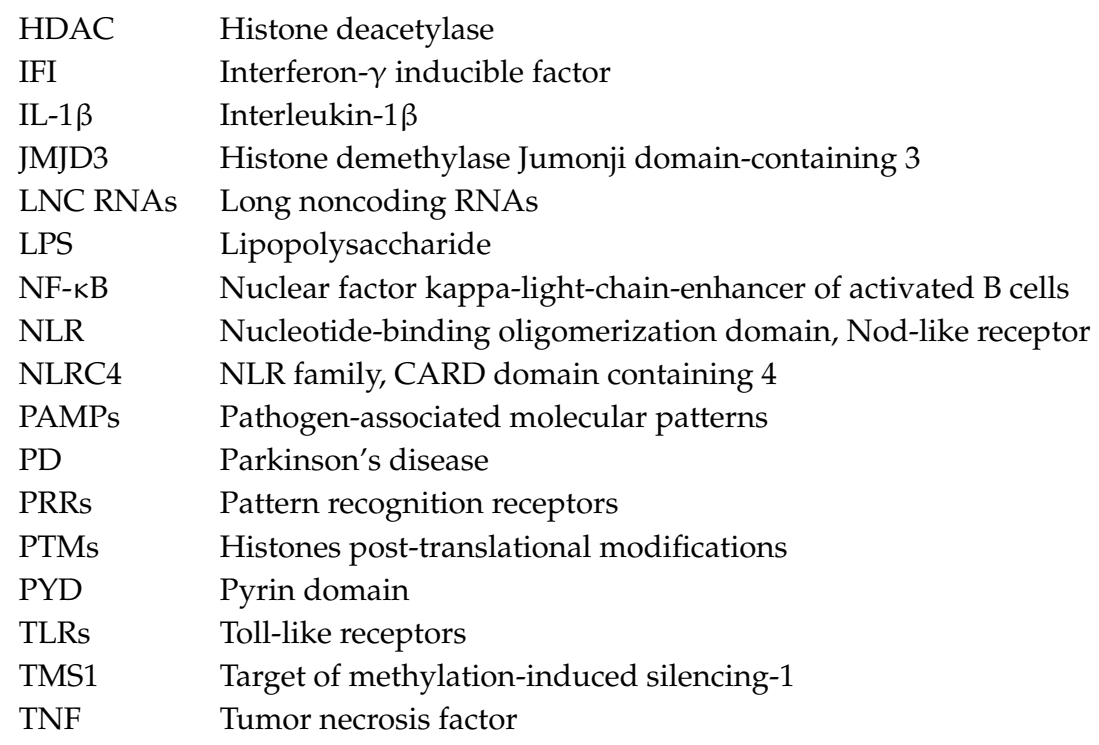

\section{References}

1. Eisenbarth, S.C.; Flavell, R.A. Innate instruction of adaptive immunity revisited: The inflammasome. EMBO Mol. Med. 2009, 1, 92-98. [CrossRef] [PubMed]

2. Swanson, K.V.; Deng, M.; Ting, J.P. The NLRP3 inflammasome: Molecular activation and regulation to therapeutics. Nat. Rev. Immunol. 2019, 19, 477-489. [CrossRef] [PubMed]

3. Christgen, S.; Place, D.E.; Kanneganti, T.D. Toward targeting inflammasomes: Insights into their regulation and activation. Cell Res. 2020, 30, 315-327. [CrossRef] [PubMed]

4. Tezcan, G.; Martynova, E.V.; Gilazieva, Z.E.; McIntyre, A.; Rizvanov, A.A.; Khaiboullina, S.F. MicroRNA Post-transcriptional Regulation of the NLRP3 Inflammasome in Immunopathologies. Front. Pharmacol. 2019, 10, 451. [CrossRef] [PubMed]

5. Allis, C.D.; Jenuwein, T. The molecular hallmarks of epigenetic control. Nat. Rev. Genet. 2016, 17, 487-500. [CrossRef] [PubMed]

6. Greenberg, M.V.C.; Bourc'his, D. The diverse roles of DNA methylation in mammalian development and disease. Nat. Rev. Mol. Cell Biol. 2019, 20, 590-607. [CrossRef]

7. Farrelly, L.A.; Thompson, R.E.; Zhao, S.; Lepack, A.E.; Lyu, Y.; Bhanu, N.V.; Zhang, B.; Loh, Y.E.; Ramakrishnan, A.; Vadodaria, K.C.; et al. Histone serotonylation is a permissive modification that enhances TFIID binding to H3K4me3. Nature 2019, 567, 535-539. [CrossRef]

8. Tessarz, P.; Kouzarides, T. Histone core modifications regulating nucleosome structure and dynamics. Nat. Rev. Mol. Cell Biol. 2014, 15, 703-708. [CrossRef]

9. Bhaumik, S.R.; Smith, E.; Shilatifard, A. Covalent modifications of histones during development and disease pathogenesis. Nat. Struct. Mol. Biol. 2007, 14, 1008-1016. [CrossRef]

10. Grillone, K.; Riillo, C.; Scionti, F.; Rocca, R.; Tradigo, G.; Guzzi, P.H.; Alcaro, S.; Di Martino, M.T.; Tagliaferri, P.; Tassone, P. Non-coding RNAs in cancer: Platforms and strategies for investigating the genomic "dark matter". J. Exp. Clin. Cancer Res. 2020, 39, 117. [CrossRef]

11. Arun, G.; Diermeier, S.D.; Spector, D.L. Therapeutic Targeting of Long Non-Coding RNAs in Cancer. Trends Mol. Med. 2018, 24, 257-277. [CrossRef] [PubMed]

12. Esteller, M. Non-coding RNAs in human disease. Nat. Rev. Genet. 2011, 12, 861-874. [CrossRef] [PubMed]

13. Martinon, F.; Burns, K.; Tschopp, J. The inflammasome: A molecular platform triggering activation of inflammatory caspases and processing of proIL-beta. Mol. Cell 2002, 10, 417-426. [CrossRef]

14. Strowig, T.; Henao-Mejia, J.; Elinav, E.; Flavell, R. Inflammasomes in health and disease. Nature 2012, 481, 278-286. [CrossRef]

15. Kawai, T.; Akira, S. Toll-like receptors and their crosstalk with other innate receptors in infection and immunity. Immunity 2011, 34, 637-650. [CrossRef]

16. Bianchi, M.E. DAMPs, PAMPs and alarmins: All we need to know about danger. J. Leukoc. Biol. 2007, 81, 1-5. [CrossRef] 
17. Latz, E.; Xiao, T.S.; Stutz, A. Activation and regulation of the inflammasomes. Nat. Rev. Immunol. 2013, 13, 397-411. [CrossRef]

18. Martinon, F.; Tschopp, J. Inflammatory caspases: Linking an intracellular innate immune system to autoinflammatory diseases. Cell 2004, 117, 561-574. [CrossRef]

19. Martinon, F.; Petrilli, V.; Mayor, A.; Tardivel, A.; Tschopp, J. Gout-associated uric acid crystals activate the NALP3 inflammasome. Nature 2006, 440, 237-241. [CrossRef]

20. Roberts, R.L.; Topless, R.K.; Phipps-Green, A.J.; Gearry, R.B.; Barclay, M.L.; Merriman, T.R. Evidence of interaction of CARD8 rs2043211 with NALP3 rs35829419 in Crohn's disease. Genes Immun. 2010, 11, 351-356. [CrossRef]

21. Villani, A.C.; Lemire, M.; Fortin, G.; Louis, E.; Silverberg, M.S.; Collette, C.; Baba, N.; Libioulle, C.; Belaiche, J.; Bitton, A.; et al. Common variants in the NLRP3 region contribute to Crohn's disease susceptibility. Nat. Genet. 2009, 41, 71-76. [CrossRef] [PubMed]

22. Cummings, J.R.; Cooney, R.M.; Clarke, G.; Beckly, J.; Geremia, A.; Pathan, S.; Hancock, L.; Guo, C.; Cardon, L.R.; Jewell, D.P. The genetics of NOD-like receptors in Crohn's disease. Tissue Antigens 2010, 76, 48-56. [CrossRef] [PubMed]

23. Kastbom, A.; Verma, D.; Eriksson, P.; Skogh, T.; Wingren, G.; Soderkvist, P. Genetic variation in proteins of the cryopyrin inflammasome influences susceptibility and severity of rheumatoid arthritis (the Swedish TIRA project). Rheumatology 2008, 47, 415-417. [CrossRef] [PubMed]

24. Duewell, P.; Kono, H.; Rayner, K.J.; Sirois, C.M.; Vladimer, G.; Bauernfeind, F.G.; Abela, G.S.; Franchi, L.; Nunez, G.; Schnurr, M.; et al. NLRP3 inflammasomes are required for atherogenesis and activated by cholesterol crystals. Nature 2010, 464, 1357-1361. [CrossRef] [PubMed]

25. Radian, A.D.; Khare, S.; Chu, L.H.; Dorfleutner, A.; Stehlik, C. ATP binding by NLRP7 is required for inflammasome activation in response to bacterial lipopeptides. Mol. Immunol. 2015, 67, 294-302. [CrossRef]

26. Dutta, D.; Dutta, S.; Veettil, M.V.; Roy, A.; Ansari, M.A.; Iqbal, J.; Chikoti, L.; Kumar, B.; Johnson, K.E.; Chandran, B. BRCA1 Regulates IFI16 Mediated Nuclear Innate Sensing of Herpes Viral DNA and Subsequent Induction of the Innate Inflammasome and Interferon-beta Responses. PLoS Pathog. 2015, 11, e1005030. [CrossRef]

27. Sharma, B.R.; Karki, R.; Kanneganti, T.D. Role of AIM2 inflammasome in inflammatory diseases, cancer and infection. Eur. J. Immunol. 2019, 49, 1998-2011. [CrossRef]

28. Liu, T.; Tang, Q.; Liu, K.; Xie, W.; Liu, X.; Wang, H.; Wang, R.F.; Cui, J. TRIM11 Suppresses AIM2 Inflammasome by Degrading AIM2 via p62-Dependent Selective Autophagy. Cell Rep. 2016, 16, 1988-2002. [CrossRef]

29. Allen, I.C.; Wilson, J.E.; Schneider, M.; Lich, J.D.; Roberts, R.A.; Arthur, J.C.; Woodford, R.M.; Davis, B.K.; Uronis, J.M.; Herfarth, H.H.; et al. NLRP12 suppresses colon inflammation and tumorigenesis through the negative regulation of noncanonical NF-kappaB signaling. Immunity 2012, 36, 742-754. [CrossRef]

30. Cui, J.; Li, Y.; Zhu, L.; Liu, D.; Songyang, Z.; Wang, H.Y.; Wang, R.F. NLRP4 negatively regulates type I interferon signaling by targeting the kinase TBK1 for degradation via the ubiquitin ligase DTX4. Nat. Immunol. 2012, 13, 387-395. [CrossRef]

31. Jounai, N.; Kobiyama, K.; Shiina, M.; Ogata, K.; Ishii, K.J.; Takeshita, F. NLRP4 negatively regulates autophagic processes through an association with beclin1. J. Immunol. 2011, 186, 1646-1655. [CrossRef] [PubMed]

32. Eibl, C.; Grigoriu, S.; Hessenberger, M.; Wenger, J.; Puehringer, S.; Pinheiro, A.S.; Wagner, R.N.; Proell, M.; Reed, J.C.; Page, R.; et al. Structural and functional analysis of the NLRP4 pyrin domain. Biochemistry 2012, 51, 7330-7341. [PubMed]

33. An, T.; Li, S.; Pan, W.; Tien, P.; Zhong, B.; Shu, H.B.; Wu, S. DYRK2 Negatively Regulates Type I Interferon Induction by Promoting TBK1 Degradation via Ser527 Phosphorylation. PLoS Pathog. 2015, 11, e1005179. [CrossRef] [PubMed]

34. Jakobs, C.; Perner, S.; Hornung, V. AIM2 Drives Joint Inflammation in a Self-DNA Triggered Model of Chronic Polyarthritis. PLoS ONE 2015, 10, e0131702. [CrossRef] [PubMed]

35. Baum, R.; Sharma, S.; Carpenter, S.; Li, Q.Z.; Busto, P.; Fitzgerald, K.A.; Marshak-Rothstein, A.; Gravallese, E.M. Cutting edge: AIM2 and endosomal TLRs differentially regulate arthritis and autoantibody production in DNase II-deficient mice. J. Immunol. 2015, 194, 873-877. [CrossRef]

36. Sester, D.P.; Sagulenko, V.; Thygesen, S.J.; Cridland, J.A.; Loi, Y.S.; Cridland, S.O.; Masters, S.L.; Genske, U.; Hornung, V.; Andoniou, C.E.; et al. Deficient NLRP3 and AIM2 Inflammasome Function in Autoimmune NZB Mice. J. Immunol. 2015, 195, 1233-1241. [CrossRef] 
37. Lech, M.; Lorenz, G.; Kulkarni, O.P.; Grosser, M.O.; Stigrot, N.; Darisipudi, M.N.; Gunthner, R.; Wintergerst, M.W.; Anz, D.; Susanti, H.E.; et al. NLRP3 and ASC suppress lupus-like autoimmunity by driving the immunosuppressive effects of TGF-beta receptor signalling. Ann. Rheum. Dis. 2015, 74, 2224-2235. [CrossRef]

38. Zhao, J.; Wang, H.; Huang, Y.; Zhang, H.; Wang, S.; Gaskin, F.; Yang, N.; Fu, S.M. Lupus nephritis: Glycogen synthase kinase 3beta promotion of renal damage through activation of the NLRP3 inflammasome in lupus-prone mice. Arthritis Rheumatol. 2015, 67, 1036-1044. [CrossRef]

39. Johann, S.; Heitzer, M.; Kanagaratnam, M.; Goswami, A.; Rizo, T.; Weis, J.; Troost, D.; Beyer, C. NLRP3 inflammasome is expressed by astrocytes in the SOD1 mouse model of ALS and in human sporadic ALS patients. Glia 2015, 63, 2260-2273. [CrossRef]

40. Son, M.Y.; Kwak, J.E.; Seol, B.; Lee, D.Y.; Jeon, H.; Cho, Y.S. A novel human model of the neurodegenerative disease GM1 gangliosidosis using induced pluripotent stem cells demonstrates inflammasome activation. J. Pathol. 2015, 237, 98-110. [CrossRef]

41. Souza, A.C.; Tsuji, T.; Baranova, I.N.; Bocharov, A.V.; Wilkins, K.J.; Street, J.M.; Alvarez-Prats, A.; Hu, X.; Eggerman, T.; Yuen, P.S.; et al. TLR4 mutant mice are protected from renal fibrosis and chronic kidney disease progression. Physiol. Rep. 2015, 3. [CrossRef] [PubMed]

42. Komada, T.; Usui, F.; Kawashima, A.; Kimura, H.; Karasawa, T.; Inoue, Y.; Kobayashi, M.; Mizushina, Y.; Kasahara, T.; Taniguchi, S.; et al. Role of NLRP3 Inflammasomes for Rhabdomyolysis-induced Acute Kidney Injury. Sci. Rep. 2015, 5, 10901. [CrossRef] [PubMed]

43. Zhuang, Y.; Yasinta, M.; Hu, C.; Zhao, M.; Ding, G.; Bai, M.; Yang, L.; Ni, J.; Wang, R.; Jia, Z.; et al. Mitochondrial dysfunction confers albumin-induced NLRP3 inflammasome activation and renal tubular injury. Am. J. Physiol. Ren. Physiol. 2015, 308, F857-F866. [CrossRef] [PubMed]

44. Chen, Y.; Li, X.; Boini, K.M.; Pitzer, A.L.; Gulbins, E.; Zhang, Y.; Li, P.L. Endothelial Nlrp3 inflammasome activation associated with lysosomal destabilization during coronary arteritis. Biochim. Biophys. Acta 2015, 1853, 396-408. [CrossRef] [PubMed]

45. Usui, F.; Shirasuna, K.; Kimura, H.; Tatsumi, K.; Kawashima, A.; Karasawa, T.; Yoshimura, K.; Aoki, H.; Tsutsui, H.; Noda, T.; et al. Inflammasome activation by mitochondrial oxidative stress in macrophages leads to the development of angiotensin II-induced aortic aneurysm. Arterioscler. Thromb. Vasc. Biol. 2015, 35, 127-136. [CrossRef] [PubMed]

46. Ketelut-Carneiro, N.; Silva, G.K.; Rocha, F.A.; Milanezi, C.M.; Cavalcanti-Neto, F.F.; Zamboni, D.S.; Silva, J.S. IL-18 triggered by the Nlrp3 inflammasome induces host innate resistance in a pulmonary model of fungal infection. J. Immunol. 2015, 194, 4507-4517. [CrossRef]

47. Feriotti, C.; Bazan, S.B.; Loures, F.V.; Araujo, E.F.; Costa, T.A.; Calich, V.L. Expression of dectin-1 and enhanced activation of NALP3 inflammasome are associated with resistance to paracoccidioidomycosis. Front. Microbiol. 2015, 6, 913. [CrossRef]

48. Borghi, M.; De Luca, A.; Puccetti, M.; Jaeger, M.; Mencacci, A.; Oikonomou, V.; Pariano, M.; Garlanda, C.; Moretti, S.; Bartoli, A.; et al. Pathogenic NLRP3 Inflammasome Activity during Candida Infection Is Negatively Regulated by IL-22 via Activation of NLRC4 and IL-1Ra. Cell Host Microbe 2015, 18, 198-209. [CrossRef]

49. Karki, R.; Man, S.M.; Malireddi, R.K.S.; Gurung, P.; Vogel, P.; Lamkanfi, M.; Kanneganti, T.D. Concerted activation of the AIM2 and NLRP3 inflammasomes orchestrates host protection against Aspergillus infection. Cell Host Microbe 2015, 17, 357-368. [CrossRef]

50. van de Veerdonk, F.L.; Joosten, L.A.; Netea, M.G. The interplay between inflammasome activation and antifungal host defense. Immunol. Rev. 2015, 265, 172-180. [CrossRef]

51. Velsko, I.M.; Chukkapalli, S.S.; Rivera-Kweh, M.F.; Zheng, D.; Aukhil, I.; Lucas, A.R.; Larjava, H.; Kesavalu, L. Periodontal pathogens invade gingiva and aortic adventitia and elicit inflammasome activation in alphavbeta6 integrin-deficient mice. Infect. Immun. 2015, 83, 4582-4593. [CrossRef] [PubMed]

52. Ramos-Junior, E.S.; Morandini, A.C.; Almeida-da-Silva, C.L.; Franco, E.J.; Potempa, J.; Nguyen, K.A.; Oliveira, A.C.; Zamboni, D.S.; Ojcius, D.M.; Scharfstein, J.; et al. A Dual Role for P2X7 Receptor during Porphyromonas gingivalis Infection. J. Dent. Res. 2015, 94, 1233-1242. [CrossRef] [PubMed]

53. Guo, W.; Wang, P.; Liu, Z.; Yang, P.; Ye, P. The activation of pyrin domain-containing-3 inflammasome depends on lipopolysaccharide from Porphyromonas gingivalis and extracellular adenosine triphosphate in cultured oral epithelial cells. BMC Oral Health 2015, 15, 133. [CrossRef] [PubMed] 
54. Hua, K.F.; Yang, F.L.; Chiu, H.W.; Chou, J.C.; Dong, W.C.; Lin, C.N.; Lin, C.Y.; Wang, J.T.; Li, L.H.; Chiu, H.W.; et al. Capsular Polysaccharide Is Involved in NLRP3 Inflammasome Activation by Klebsiella pneumoniae Serotype K1. Infect. Immun. 2015, 83, 3396-3409. [CrossRef]

55. Matsuo, J.; Nakamura, S.; Takeda, S.; Ishida, K.; Yamazaki, T.; Yoshida, M.; Chiba, H.; Hui, S.P.; Yamaguchi, H. Synergistic Costimulatory Effect of Chlamydia pneumoniae with Carbon Nanoparticles on NLRP3 Inflammasome-Mediated Interleukin-1beta Secretion in Macrophages. Infect. Immun. 2015, 83, 2917-2925. [CrossRef]

56. Li, X.; Liu, S.; Luo, J.; Liu, A.; Tang, S.; Liu, S.; Yu, M.; Zhang, Y. Helicobacter pylori induces IL-1beta and IL-18 production in human monocytic cell line through activation of NLRP3 inflammasome via ROS signaling pathway. Pathog. Dis. 2015, 73. [CrossRef]

57. Guo, S.; Yang, C.; Diao, B.; Huang, X.; Jin, M.; Chen, L.; Yan, W.; Ning, Q.; Zheng, L.; Wu, Y.; et al. The NLRP3 Inflammasome and IL-1beta Accelerate Immunologically Mediated Pathology in Experimental Viral Fulminant Hepatitis. PLoS Pathog. 2015, 11, e1005216.

58. Ye, W.; Lei, Y.; Yu, M.; Xu, Y.; Cao, M.; Yu, L.; Zhang, L.; Li, P.; Bai, W.; Xu, Z.; et al. NLRP3 inflammasome is responsible for Hantavirus inducing interleukin-1beta in THP-1 cells. Int. J. Mol. Med. 2015, 35, 1633-1640. [CrossRef]

59. Wang, S.L.; Zhao, G.; Zhu, W.; Dong, X.M.; Liu, T.; Li, Y.Y.; Song, W.G.; Wang, Y.Q. Herpes simplex virus-1 infection or Simian virus 40-mediated immortalization of corneal cells causes permanent translocation of NLRP3 to the nuclei. Int. J. Ophthalmol. 2015, 8, 46-51.

60. Wang, C.; Shi, X.; Zhang, X.; Wang, A.; Wang, L.; Chen, J.; Deng, R.; Zhang, G. The Endoribonuclease Activity Essential for the Nonstructural Protein 11 of Porcine Reproductive and Respiratory Syndrome Virus to Inhibit NLRP3 Inflammasome-Mediated IL-1beta Induction. DNA Cell Biol. 2015, 34, 728-735. [CrossRef]

61. Lien, T.S.; Sun, D.S.; Chang, C.M.; Wu, C.Y.; Dai, M.S.; Chan, H.; Wu, W.S.; Su, S.H.; Lin, Y.Y.; Chang, H.H. Dengue virus and antiplatelet autoantibodies synergistically induce haemorrhage through Nlrp3-inflammasome and FcgammaRIII. Thromb. Haemost. 2015, 113, 1060-1070. [PubMed]

62. Nuvolone, M.; Sorce, S.; Schwarz, P.; Aguzzi, A. Prion pathogenesis in the absence of NLRP3/ASC inflammasomes. PLoS ONE 2015, 10, e0117208. [CrossRef] [PubMed]

63. Motta, V.N.; Markle, J.G.; Gulban, O.; Mortin-Toth, S.; Liao, K.C.; Mogridge, J.; Steward, C.A.; Danska, J.S. Identification of the inflammasome Nlrp1b as the candidate gene conferring diabetes risk at the Idd4.1 locus in the nonobese diabetic mouse. J. Immunol. 2015, 194, 5663-5673. [CrossRef] [PubMed]

64. Zhao, Y.; Forst, C.V.; Sayegh, C.E.; Wang, I.M.; Yang, X.; Zhang, B. Molecular and genetic inflammation networks in major human diseases. Mol. Biosyst. 2016, 12, 2318-2341. [CrossRef]

65. Welter, D.; MacArthur, J.; Morales, J.; Burdett, T.; Hall, P.; Junkins, H.; Klemm, A.; Flicek, P.; Manolio, T.; Hindorff, L.; et al. The NHGRI GWAS Catalog, a curated resource of SNP-trait associations. Nucl. Acids Res. 2014, 42, D1001-D1006. [CrossRef]

66. Zhao, Y.; Usatyuk, P.V.; Gorshkova, I.A.; He, D.; Wang, T.; Moreno-Vinasco, L.; Geyh, A.S.; Breysse, P.N.; Samet, J.M.; Spannhake, E.W.; et al. Regulation of COX-2 expression and IL-6 release by particulate matter in airway epithelial cells. Am. J. Respir. Cell Mol. Biol. 2009, 40, 19-30. [CrossRef]

67. Dinarello, C.A. Biologic basis for interleukin-1 in disease. Blood 1996, 87, 2095-2147. [CrossRef]

68. Voronov, E.; Carmi, Y.; Apte, R.N. The role IL-1 in tumor-mediated angiogenesis. Front. Physiol. $2014,5,114$. [CrossRef]

69. Schneider, S.L.; Ross, A.L.; Grichnik, J.M. Do inflammatory pathways drive melanomagenesis? Exp. Dermatol. 2015, 24, 86-90. [CrossRef]

70. Paugh, S.W.; Bonten, E.J.; Savic, D.; Ramsey, L.B.; Thierfelder, W.E.; Gurung, P.; Malireddi, R.K.; Actis, M.; Mayasundari, A.; Min, J.; et al. NALP3 inflammasome upregulation and CASP1 cleavage of the glucocorticoid receptor cause glucocorticoid resistance in leukemia cells. Nat. Genet. 2015, 47, 607-614. [CrossRef]

71. Wilson, J.E.; Petrucelli, A.S.; Chen, L.; Koblansky, A.A.; Truax, A.D.; Oyama, Y.; Rogers, A.B.; Brickey, W.J.; Wang, Y.; Schneider, M.; et al. Inflammasome-independent role of AIM2 in suppressing colon tumorigenesis via DNA-PK and Akt. Nat. Med. 2015, 21, 906-913. [CrossRef] [PubMed]

72. Allam, R.; Maillard, M.H.; Tardivel, A.; Chennupati, V.; Bega, H.; Yu, C.W.; Velin, D.; Schneider, P.; Maslowski, K.M. Epithelial NAIPs protect against colonic tumorigenesis. J. Exp. Med. 2015, 212, 369-383. [CrossRef] [PubMed] 
73. Lee, C.H.; Chang, J.S.; Syu, S.H.; Wong, T.S.; Chan, J.Y.; Tang, Y.C.; Yang, Z.P.; Yang, W.C.; Chen, C.T.; Lu, S.C.; et al. IL-1beta promotes malignant transformation and tumor aggressiveness in oral cancer. J. Cell. Physiol. 2015, 230, 875-884. [CrossRef] [PubMed]

74. Williams, T.M.; Leeth, R.A.; Rothschild, D.E.; Coutermarsh-Ott, S.L.; McDaniel, D.K.; Simmons, A.E.; Heid, B.; Cecere, T.E.; Allen, I.C. The NLRP1 inflammasome attenuates colitis and colitis-associated tumorigenesis. J. Immunol. 2015, 194, 3369-3380. [CrossRef] [PubMed]

75. Chen, G.Y.; Liu, M.; Wang, F.; Bertin, J.; Nunez, G. A functional role for Nlrp6 in intestinal inflammation and tumorigenesis. J. Immunol. 2011, 186, 7187-7194. [CrossRef]

76. Allen, I.C.; TeKippe, E.M.; Woodford, R.M.; Uronis, J.M.; Holl, E.K.; Rogers, A.B.; Herfarth, H.H.; Jobin, C.; Ting, J.P. The NLRP3 inflammasome functions as a negative regulator of tumorigenesis during colitis-associated cancer. J. Exp. Med. 2010, 207, 1045-1056. [CrossRef]

77. Hu, B.; Elinav, E.; Huber, S.; Booth, C.J.; Strowig, T.; Jin, C.; Eisenbarth, S.C.; Flavell, R.A. Inflammation-induced tumorigenesis in the colon is regulated by caspase-1 and NLRC4. Proc. Natl. Acad. Sci. USA 2010, 107, 21635-21640. [CrossRef]

78. Okamoto, M.; Liu, W.; Luo, Y.; Tanaka, A.; Cai, X.; Norris, D.A.; Dinarello, C.A.; Fujita, M. Constitutively active inflammasome in human melanoma cells mediating autoinflammation via caspase-1 processing and secretion of interleukin-1beta. J. Biol. Chem. 2010, 285, 6477-6488. [CrossRef]

79. Lewis, A.M.; Varghese, S.; Xu, H.; Alexander, H.R. Interleukin-1 and cancer progression: The emerging role of interleukin-1 receptor antagonist as a novel therapeutic agent in cancer treatment. J. Transl. Med. 2006, 4, 48. [CrossRef]

80. Ahmad, I.; Muneer, K.M.; Tamimi, I.A.; Chang, M.E.; Ata, M.O.; Yusuf, N. Thymoquinone suppresses metastasis of melanoma cells by inhibition of NLRP3 inflammasome. Toxicol. Appl. Pharmacol. 2013, 270, 70-76. [CrossRef]

81. Wei, Q.; Mu, K.; Li, T.; Zhang, Y.; Yang, Z.; Jia, X.; Zhao, W.; Huai, W.; Guo, P.; Han, L. Deregulation of the NLRP3 inflammasome in hepatic parenchymal cells during liver cancer progression. Lab. Investig. 2014, 94, 52-62. [CrossRef] [PubMed]

82. Ciccarelli, F.; De Martinis, M.; Ginaldi, L. An update on autoinflammatory diseases. Curr. Med. Chem. 2014, 21, 261-269. [CrossRef] [PubMed]

83. Martinon, F.; Aksentijevich, I. New players driving inflammation in monogenic autoinflammatory diseases. Nat. Rev. Rheumatol. 2015, 11, 11-20. [CrossRef] [PubMed]

84. de Torre-Minguela, C.; Mesa Del Castillo, P.; Pelegrin, P. The NLRP3 and Pyrin Inflammasomes: Implications in the Pathophysiology of Autoinflammatory Diseases. Front. Immunol. 2017, 8, 43. [CrossRef] [PubMed]

85. Alvarez-Errico, D.; Vento-Tormo, R.; Ballestar, E. Genetic and Epigenetic Determinants in Autoinflammatory Diseases. Front. Immunol. 2017, 8, 318. [CrossRef]

86. Surace, A.E.A.; Hedrich, C.M. The Role of Epigenetics in Autoimmune/Inflammatory Disease. Front. Immunol. 2019, 10, 1525. [CrossRef]

87. Vento-Tormo, R.; Alvarez-Errico, D.; Garcia-Gomez, A.; Hernandez-Rodriguez, J.; Bujan, S.; Basagana, M.; Mendez, M.; Yague, J.; Juan, M.; Arostegui, J.I.; et al. DNA demethylation of inflammasome-associated genes is enhanced in patients with cryopyrin-associated periodic syndromes. J. Allergy Clin. Immunol. 2017, 139, 202-211. [CrossRef]

88. Brandt, D.; Sohr, E.; Pablik, J.; Schnabel, A.; Kapplusch, F.; Mabert, K.; Girschick, J.H.; Morbach, H.; Thielemann, F.; Hofmann, S.R.; et al. CD14(+) monocytes contribute to inflammation in chronic nonbacterial osteomyelitis (CNO) through increased NLRP3 inflammasome expression. Clin. Immunol. 2018, 196, 77-84. [CrossRef]

89. Omenetti, A.; Carta, S.; Delfino, L.; Martini, A.; Gattorno, M.; Rubartelli, A. Increased NLRP3-dependent interleukin 1beta secretion in patients with familial Mediterranean fever: Correlation with MEFV genotype. Ann. Rheum. Dis. 2014, 73, 462-469. [CrossRef]

90. Wei, M.; Wang, L.; Wu, T.; Xi, J.; Han, Y.; Yang, X.; Zhang, D.; Fang, Q.; Tang, B. NLRP3 Activation Was Regulated by DNA Methylation Modification during Mycobacterium tuberculosis Infection. Biomed. Res. Int. 2016, 2016, 4323281. [CrossRef]

91. Lecoeur, H.; Prina, E.; Rosazza, T.; Kokou, K.; N’Diaye, P.; Aulner, N.; Varet, H.; Bussotti, G.; Xing, Y.; Milon, G.; et al. Targeting Macrophage Histone H3 Modification as a Leishmania Strategy to Dampen the NF-kappaB/NLRP3-Mediated Inflammatory Response. Cell Rep. 2020, 30, 1870-1882. [CrossRef] [PubMed] 
92. Salminen, A.; Kauppinen, A.; Hiltunen, M.; Kaarniranta, K. Epigenetic regulation of ASC/TMS1 expression: Potential role in apoptosis and inflammasome function. Cell. Mol. Life Sci. 2014, 71, 1855-1864. [CrossRef] [PubMed]

93. Moossavi, M.; Parsamanesh, N.; Bahrami, A.; Atkin, S.L.; Sahebkar, A. Role of the NLRP3 inflammasome in cancer. Mol. Cancer 2018, 17, 158. [CrossRef] [PubMed]

94. Karan, D. Inflammasomes: Emerging Central Players in Cancer Immunology and Immunotherapy. Front. Immunol. 2018, 9, 3028. [CrossRef] [PubMed]

95. Protti, M.P.; De Monte, L. Dual Role of Inflammasome Adaptor ASC in Cancer. Front. Cell Dev. Biol. 2020, 8, 40. [CrossRef]

96. Liu, C.C.; Huang, Z.X.; Li, X.; Shen, K.F.; Liu, M.; Ouyang, H.D.; Zhang, S.B.; Ruan, Y.T.; Zhang, X.L.; Wu, S.L.; et al. Upregulation of NLRP3 via STAT3-dependent histone acetylation contributes to painful neuropathy induced by bortezomib. Exp. Neurol. 2018, 302, 104-111. [CrossRef]

97. Kose-Vogel, N.; Stengel, S.; Gardey, E.; Kirchberger-Tolstik, T.; Reuken, P.A.; Stallmach, A.; Bruns, T. Transcriptional Suppression of the NLRP3 Inflammasome and Cytokine Release in Primary Macrophages by Low-Dose Anthracyclines. Cells 2019, 9, 79. [CrossRef]

98. Lamot, L.; Blažeković, A.; Jerčić, K.G.; Ivković, T.C.; Vidović, M.; Lamot, M.; Kapitanović, S.; Borovečki, F.; Harjaček, M. Epigenetic Alterations in Juvenile Spondyloarthritis Patients: A Preliminary Study of Selected Genes Promoter Methylation and Silencing. SN Compr. Clin. Med. 2019, 1, 496-501. [CrossRef]

99. Sun, H.J.; Ren, X.S.; Xiong, X.Q.; Chen, Y.Z.; Zhao, M.X.; Wang, J.J.; Zhou, Y.B.; Han, Y.; Chen, Q.; Li, Y.H.; et al. NLRP3 inflammasome activation contributes to VSMC phenotypic transformation and proliferation in hypertension. Cell Death Dis. 2017, 8, e3074. [CrossRef]

100. Zhang, M.J.; Zhao, Q.C.; Xia, M.X.; Chen, J.; Chen, Y.T.; Cao, X.; Liu, Y.; Yuan, Z.Q.; Wang, X.Y.; $\mathrm{Xu}, \mathrm{Y}$. The HDAC3 inhibitor RGFP966 ameliorated ischemic brain damage by downregulating the AIM2 inflammasome. FASEB J. 2020, 34, 648-662. [CrossRef]

101. Huang, M.; Wang, Q.; Long, F.; Di, Y.; Wang, J.; Zhun Zhu, Y.; Liu, X. Jmjd3 regulates inflammasome activation and aggravates DSS-induced colitis in mice. FASEB J. 2020, 34, 4107-4119. [CrossRef] [PubMed]

102. Neudecker, V.; Haneklaus, M.; Jensen, O.; Khailova, L.; Masterson, J.C.; Tye, H.; Biette, K.; Jedlicka, P.; Brodsky, K.S.; Gerich, M.E.; et al. Myeloid-derived miR-223 regulates intestinal inflammation via repression of the NLRP3 inflammasome. J. Exp. Med. 2017, 214, 1737-1752. [CrossRef] [PubMed]

103. Feng, Z.; Qi, S.; Zhang, Y.; Qi, Z.; Yan, L.; Zhou, J.; He, F.; Li, Q.; Yang, Y.; Chen, Q.; et al. Ly6G+ neutrophilderived miR-223 inhibits the NLRP3 inflammasome in mitochondrial DAMP-induced acute lung injury. Cell Death Dis. 2017, 8, e3170. [CrossRef] [PubMed]

104. Li, X.; Zhang, Y.; Zhang, H.; Liu, X.; Gong, T.; Li, M.; Sun, L.; Ji, G.; Shi, Y.; Han, Z.; et al. MiRNA-223 promotes gastric cancer invasion and metastasis by targeting tumor suppressor EPB41L3. Mol. Cancer Res. 2011, 9, 824-833. [CrossRef] [PubMed]

105. Bandyopadhyay, S.; Lane, T.; Venugopal, R.; Parthasarathy, P.T.; Cho, Y.; Galam, L.; Lockey, R.; Kolliputi, N. MicroRNA-133a-1 regulates inflammasome activation through uncoupling protein-2. Biochem. Biophys. Res. Commun. 2013, 439, 407-412. [CrossRef] [PubMed]

106. Li, S.; Liang, X.; Ma, L.; Shen, L.; Li, T.; Zheng, L.; Sun, A.; Shang, W.; Chen, C.; Zhao, W.; et al. MiR-22 sustains NLRP3 expression and attenuates H. pylori-induced gastric carcinogenesis. Oncogene 2018, 37, 884-896. [CrossRef]

107. Li, D.; Yang, H.; Ma, J.; Luo, S.; Chen, S.; Gu, Q. MicroRNA-30e regulates neuroinflammation in MPTP model of Parkinson's disease by targeting Nlrp3. Hum. Cell 2018, 31, 106-115. [CrossRef]

108. Zhou, Y.; Lu, M.; Du, R.H.; Qiao, C.; Jiang, C.Y.; Zhang, K.Z.; Ding, J.H.; Hu, G. MicroRNA-7 targets Nod-like receptor protein 3 inflammasome to modulate neuroinflammation in the pathogenesis of Parkinson's disease. Mol. Neurodegener. 2016, 11, 28. [CrossRef]

109. Chen, Z.; Dong, W.H.; Chen, Q.; Li, Q.G.; Qiu, Z.M. Downregulation of miR-199a-3p mediated by the CtBP2-HDAC1-FOXP3 transcriptional complex contributes to acute lung injury by targeting NLRP1. Int. J. Biol. Sci. 2019, 15, 2627-2640. [CrossRef]

110. Boxberger, N.; Hecker, M.; Zettl, U.K. Dysregulation of Inflammasome Priming and Activation by MicroRNAs in Human Immune-Mediated Diseases. J. Immunol. 2019, 202, 2177-2187. [CrossRef] 
111. Zhou, T.; Xiang, D.K.; Li, S.N.; Yang, L.H.; Gao, L.F.; Feng, C. MicroRNA-495 Ameliorates Cardiac Microvascular Endothelial Cell Injury and Inflammatory Reaction by Suppressing the NLRP3 Inflammasome Signaling Pathway. Cell. Physiol. Biochem. 2018, 49, 798-815. [CrossRef] [PubMed]

112. Gu, T.T.; Song, L.; Chen, T.Y.; Wang, X.; Zhao, X.J.; Ding, X.Q.; Yang, Y.Z.; Pan, Y.; Zhang, D.M.; Kong, L.D. Fructose downregulates miR-330 to induce renal inflammatory response and insulin signaling impairment: Attenuation by morin. Mol. Nutr. Food Res. 2017, 61. [CrossRef] [PubMed]

113. Coucha, M.; Mohamed, I.N.; Elshaer, S.L.; Mbata, O.; Bartasis, M.L.; El-Remessy, A.B. High fat diet dysregulates microRNA-17-5p and triggers retinal inflammation: Role of endoplasmic-reticulum-stress. World J. Diabetes 2017, 8, 56-65. [CrossRef] [PubMed]

114. Mearini, E.; Poli, G.; Cochetti, G.; Boni, A.; Egidi, M.G.; Brancorsini, S. Expression of urinary miRNAs targeting NLRs inflammasomes in bladder cancer. Onco Targets Ther. 2017, 10, 2665-2673. [CrossRef]

115. Shen, M.; Meng, L. Peripheral blood miR-372 as a biomarker for ulcerative colitis via direct targeting of NLRP12. Exp. Ther. Med. 2019, 18, 1486-1492. [CrossRef]

116. Momeni, M.; Reza Mirzaei, M.; Zainodini, N.; Hassanshahi, G.; Arababadi, M.K. MiR-143 induces expression of AIM2 and ASC in Jurkat cell line. Iran. J. Immunol. 2013, 10, 103-109.

117. Fonseca-Sanchez, M.A.; Perez-Plasencia, C.; Fernandez-Retana, J.; Arechaga-Ocampo, E.; Marchat, L.A.; Rodriguez-Cuevas, S.; Bautista-Pina, V.; Arellano-Anaya, Z.E.; Flores-Perez, A.; Diaz-Chavez, J.; et al. MicroRNA-18b is upregulated in breast cancer and modulates genes involved in cell migration. Oncol. Rep. 2013, 30, 2399-2410. [CrossRef]

118. Bauernfeind, F.; Rieger, A.; Schildberg, F.A.; Knolle, P.A.; Schmid-Burgk, J.L.; Hornung, V. NLRP3 inflammasome activity is negatively controlled by miR-223. J. Immunol. 2012, 189, 4175-4181. [CrossRef]

119. Semper, R.P.; Mejias-Luque, R.; Gross, C.; Anderl, F.; Muller, A.; Vieth, M.; Busch, D.H.; Prazeres da Costa, C.; Ruland, J.; Gross, O.; et al. Helicobacter pylori-induced IL-1beta secretion in innate immune cells is regulated by the NLRP3 inflammasome and requires the cag pathogenicity island. J. Immunol. 2014, 193, 3566-3576. [CrossRef]

120. Castano-Rodriguez, N.; Kaakoush, N.O.; Goh, K.L.; Fock, K.M.; Mitchell, H.M. The NOD-like receptor signalling pathway in Helicobacter pylori infection and related gastric cancer: A case-control study and gene expression analyses. PLoS ONE 2014, 9, e98899. [CrossRef]

121. Wang, H.; Bei, Y.; Shen, S.; Huang, P.; Shi, J.; Zhang, J.; Sun, Q.; Chen, Y.; Yang, Y.; Xu, T.; et al. MiR-21-3p controls sepsis-associated cardiac dysfunction via regulating SORBS2. J. Mol. Cell. Cardiol. 2016, 94, 43-53. [CrossRef] [PubMed]

122. Xue, Z.; Xi, Q.; Liu, H.; Guo, X.; Zhang, J.; Zhang, Z.; Li, Y.; Yang, G.; Zhou, D.; Yang, H.; et al. MiR-21 promotes NLRP3 inflammasome activation to mediate pyroptosis and endotoxic shock. Cell Death Dis. 2019, 10, 461. [CrossRef] [PubMed]

123. Junn, E.; Lee, K.W.; Jeong, B.S.; Chan, T.W.; Im, J.Y.; Mouradian, M.M. Repression of alpha-synuclein expression and toxicity by microRNA-7. Proc. Natl. Acad. Sci. USA 2009, 106, 13052-13057. [CrossRef] [PubMed]

124. Heneka, M.T.; Kummer, M.P.; Latz, E. Innate immune activation in neurodegenerative disease. Nat. Rev. Immunol. 2014, 14, 463-477. [CrossRef] [PubMed]

125. Poli, G.; Brancorsini, S.; Cochetti, G.; Barillaro, F.; Egidi, M.G.; Mearini, E. Expression of inflammasome-related genes in bladder cancer and their association with cytokeratin 20 messenger RNA. Urol. Oncol. 2015, 33, 505.e1-505.e7. [CrossRef] [PubMed]

126. Poli, G.; Cochetti, G.; Boni, A.; Egidi, M.G.; Brancorsini, S.; Mearini, E. Characterization of inflammasomerelated genes in urine sediments of patients receiving intravesical BCG therapy. Urol. Oncol. 2017, 35, 674.e19-674.e24. [CrossRef] [PubMed]

(C) 2020 by the authors. Licensee MDPI, Basel, Switzerland. This article is an open access article distributed under the terms and conditions of the Creative Commons Attribution (CC BY) license (http://creativecommons.org/licenses/by/4.0/). 